\title{
Utilization of guava extract as additive antioxidant in diets of Japanese quail breeders (Coturnix japonica)
}

Utilização de extrato de goiaba como aditivo antioxidante na ração de codornas (Coturnix japonica)

\author{
XAVIER, Hyara Paula Fleuri ${ }^{1}$; \\ 0000-0002-7077-2861 \\ LEANDRO, Nadja Susana Mogyca ${ }^{1}$ \\ 0000-0002-6525-9975 \\ CONCEIÇÃO, Edemilson Cardoso $\mathrm{Da}^{2}$ \\ 0000-0003-4113-2686 \\ MASCARENHAS, Alessandra Gimenez ${ }^{1}$ \\ 0000-0001-8333-0723
}

ARNHOLD, Emmanuel ${ }^{1}$

0000-0003-0922-146X

\author{
MELLO, Heloisa Helena De Carvalho ${ }^{1^{*}}$ \\ 0000-0002-0312-7424
}

BORGES, Kamilla Martins ${ }^{1}$

0000-0003-3187-2015

OLIVEIRA, Maryelle Durães de ${ }^{1}$ 0000-0002-1452-2702

PEREIRA, Ligia Sarneiro ${ }^{1}$

0000-0002-5204-1213

${ }^{1}$ Universidade Federal de Goiás, Escola da Veterinária e Zootecnia, Departamento de Zootecnia, Goiânia, Goiás, Brasil

${ }^{2}$ Universidade Federal de Goiás, Faculdade de Farmácia, Goiânia, Goiás, Brasil

* Corresponding author: heloisamello@gmail.com

\section{SUMMARY}

The aim of this study was to evaluate the guava extract as an antioxidant additive in diets of Japanese quail breeders on the performance and egg's quality. The experiment was conducted at University Federal of Goias. A total of 384 Japanese quail breeders were used, distributed in four treatments, with six replicates, with a total of 12 females and four males in each replicate. The treatments were performed with four levels of guava extract in the diets $(0.0 \%, 0.3 \%, 0.6 \%$ and $0.9 \%)$. The guava extract contained the ellagic acid, considered the guava antioxidant active principle. The diets were isonutritive. Feed and water were offered ad libitum. The experimental period was 84 days. Egg production, feed intake, feed conversion ratio, egg mass, body weight variation and egg quality were evaluated. The results were submitted to analysis of variance and regression analysis. The adopted probability was 5\%. Egg production, feed intake, feed conversion ratio and egg mass were not influenced by the use of guava extract. The yolk and albumen height, the Haugh Unit and the yolk and albumen index decreased linearly as the levels of guava extract in the diet increased. The diameter of the albumen was higher with the use of $0.48 \%$ of guava extract in the diet. The yolk color was affected by the guava extract, 
presenting a darker color with $0.50 \%$ of guava extract in the diet. It was concluded that the guava extract used as an antioxidant additive does not improve the performance and egg quality of Japanese quails.

Key-words: additive, antioxidant, breeder, ellagic acid, yolk

\section{RESUMO}

Objetivou-se avaliar o efeito do extrato de goiaba em dietas de matrizes de codornas japonesas (Coturnix japonica) sobre o desempenho produtivo e a qualidade dos ovos férteis. O experimento foi realizado na Universidade Federal de Goiás. Foram utilizadas 384 matrizes de codornas Japonesas, distribuídas em 4 tratamentos, com 6 repetições, total de 12 fêmeas e 4 machos em cada repetição. Os tratamentos foram quatro níveis de extrato de goiaba nas rações $(0,0 \%, 0,3 \%, 0,6 \%$ e $0,9 \%)$. O extrato de goiaba continha $2,13 \%$ de ácido elágico, considerado um princípio antioxidante da goiaba. As rações foram isonutritivas. $\mathrm{O}$ período experimental foi de 84 dias. Foi avaliada a produção de ovos, consumo de ração, conversão alimentar, massa de ovos, ganho de peso e qualidade interna e externa dos ovos. Os resultados foram submetidos à análise de variância e de regressão com $5 \%$ de probabilidade. A utilização do extrato de goiaba não influenciou a produção de ovos, o consumo de ração, a conversão alimentar e a massa de ovos. A altura de gema e albúmen, a unidade Haugh e o índice de gema e de albúmen diminuíram linearmente à medida em que os níveis de extrato de goiaba na ração aumentaram. $\mathrm{O}$ diâmetro do albúmen foi maior com $0,48 \%$ de extrato de goiaba na ração. A coloração da gema foi influenciada pela utilização do extrato, apresentando coloração mais escura com $0,498 \%$ de extrato de goiaba na ração. Conclui-se que o extrato de goiaba não melhora o desempenho e qualidade dos ovos de codornas japonesas.

Palavras-chave: ácido elágico, aditivo, antioxidante, gema, matriz

\section{INTRODUCTION}

The quail's production has steadily increased in Brazil. The improvement on the quality of the newborn quails might enhance the productivity and rentability of this activity. Fertile eggs in better qualities having a good membrane structure can result in better newborn quails. Due to its composition, eggs are susceptible to lipid peroxidation (Du e Ahn, 2000). Therefore, using antioxidants compounds can be an alternative to slow the lipid oxidation and improve the quality of the incubated eggs and the newborn quails.

The birds' eggs have a high lipid concentration, which are essential to the embryo development, due to its source of energy, fatty acids and fat-soluble vitamins (Ferreira et al., 2010). In the embryo development, the lipids in the egg yolk undergo additional saturation in the liver and produce long chain polyunsaturated fatty acids (PUFAs) (Ferreira et al., 2010). PUFAs are very susceptible to oxidation and are in high concentration in the embryo's tissues, as well as in the sperm's membranes (Pappas et al., 2008). According to Barreiros et al. (2006), an important fact that influences the antioxidant activity of flavonoids is their interaction with biomembranes and that the lipophilicity of the flavonoid indicates the incorporation of the membrane, which is the target of most reactive oxygen and nitrogen species. For that matter, it is 
possible that the use of an antioxidant additive in the quail breeders' diet might impact the ova's quality through the cellular membrane protection and the yolk lipid content, enhancing the eggs production and quality.

The guava processing (Psidium guajava $L$.) produces residue that can be used in the animal's diet, containing high concentration of vitamins and total phenolic compounds (Oliveira et al., 2011). The phenolic compounds present in the guava are antioxidants that have oxydo-reduction properties, which can play an important role in the free radical's absorption and neutralization, chelating the oxygen or decomposing the peroxides (Degáspari, 2004). The use of guava derivatives as feed ingredients for poultry has been reported (Silva et al., 2009; Lira et al., 2009; Mahmoud et al., 2013; Camelo et al., 2015). However, the effect of using a standardized extract produced from the guava with the antioxidant purpose, has still to be enlightened. The ellagic acid is a phenolic compound with antioxidant activity (Cruz-Antonio et al., 2010). These phenolic compounds found in fruits have been studied as antioxidants additive (Seeram et al., 2005; Ahmed, 2015; Oliveira et al., 2018a). The use of the guava residue extract as antioxidant in quail's diet might lower the costs and present positive effects, being an alternative to the synthetic antioxidants. In this regard, it was aimed to evaluate the guava extract effect (Pisidium guajava L.) as an antioxidant additive in the diet of Japanese quail breeders (Coturnix japonica) in the production phase on the breeders performance and the fertile eggs' quality.

\section{MATERIALS AND METHODS}

The experiment was conducted at the School of Veterinary and Animal Science of the Federal University of Goias. The Ethics Committee in the Use of Animals approved all procedures, under the protocol 052/15.

384 Japanese quail's breeders of 133 days old were used and distributed in a completely randomized design, with four treatments and six repetitions. 12 females and four males were used per repetition, totalizing 288 females and 96 males. The treatments were composed by one diet without the guava extract and three others with increasing levels of guava extract inclusion (Treatments: $0.0 \% ; 0.3 \% ; 0.6 \%$; and $0.9 \%)$. The experimental diets were isonutritives and formulated according to Rostagno et al. (2011) (Table 1). The maize starch was used as an inert ingredient to be replaced by the guava extract. The animals had free access to water and feed during the entire experiment.

The guava extract had $2.13 \%$ of ellagic acid and it was obtained in the Laboratory for Research, Development and Innovation of Bioproducts, Faculty of Pharmacy, Federal University of Goias. To obtain the guava extract, the residue from the industrial processing of the guava fruits was used (pulp waste, peel and seeds). It was provided by the Predilecta Alimentos Industry LTDA, which were stored in $20^{\circ} \mathrm{C}$ in a cold storage. Subsequently, they were defrosted for 48 hours, dehydrated in a forced air circulation oven in $40^{\circ} \mathrm{C}$ until the attainment of a constant mass, they were also grinded in a knife and hammer mill and the obtained powder was stored free of light and humidity. The powder resulted from the milling underwent the percolating extraction process, using ethylic alcohol as a solvent and the alcoholic scale was determined by the 
optimization of the extraction method by Box Behnken. The obtained extract was concentrated with the cooler, until the complete evaporation of the ethylic alcohol. The extract used in its liquid form was pulverized on the milled corn at the moment of the macro ingredients preparation to the diet production. The extract was incorporated in each feed replacing the starch.

The poultry were housed in galvanized wire cages equipped with nipple-type drinkers, trough type feeders and eggs collection fence, in a masonry poultry housing and lateral closing curtains. The maximum and minimum temperatures during the experiment were $34^{\circ} \mathrm{C}$ and $22^{\circ} \mathrm{C}$, respectively. The handling of opening and closing the curtains, to a better control of the aviary temperature, were done at 8 a.m. and 5 p.m., every day. The experiment was composed by four production cycles of 21 days, meaning 84 days of experimental period.

Table 1 - Composition of experimental diets

\begin{tabular}{|c|c|c|c|c|}
\hline \multirow[b]{2}{*}{ Ingredients (\%) } & \multicolumn{4}{|c|}{ Treatments } \\
\hline & $\mathrm{T} 1$ & $\mathrm{~T} 2$ & $\mathrm{~T} 3$ & $\mathrm{~T} 4$ \\
\hline Corn & 54.681 & 54.681 & 54.681 & 54.681 \\
\hline Soyben Meal & 32.621 & 32.621 & 32.621 & 32.621 \\
\hline Guava extract & 0.000 & 0.300 & 0.600 & 0.900 \\
\hline Starch & 0.900 & 0.600 & 0.300 & 0 \\
\hline Oil vegetable & 1.470 & 1.470 & 1.470 & 1.470 \\
\hline Calcarium & 5.780 & 5.780 & 5.780 & 5.780 \\
\hline DL-Methionine & 0.352 & 0.352 & 0.352 & 0.352 \\
\hline L-Lysine HCl & 0.189 & 0.189 & 0.189 & 0.189 \\
\hline L-Tryptophan & 0.006 & 0.006 & 0.006 & 0.006 \\
\hline Premix Supplement* & 4.000 & 4.000 & 4.000 & 4.000 \\
\hline TOTAL & 100.00 & 100.00 & 100.00 & 100.00 \\
\hline \multicolumn{5}{|c|}{ Calculated composition } \\
\hline $\begin{array}{l}\text { Metabolizable energy } \\
\text { Kcal/Kg }\end{array}$ & 2.800 & 2.800 & 2.800 & 2.800 \\
\hline Sodium \% & 0.188 & 0.188 & 0.188 & 0.188 \\
\hline Calcium \% & 3.099 & 3.099 & 3.099 & 3.099 \\
\hline $\begin{array}{l}\text { Avaiable phosphorus } \\
\%\end{array}$ & 0.406 & 0.406 & 0.406 & 0.406 \\
\hline Crude protein $\%$ & 19.94 & 19.94 & 19.94 & 19.94 \\
\hline Digestible lysine \% & 1.083 & 1.083 & 1.083 & 1.083 \\
\hline $\begin{array}{l}\text { Digestible Met. + Cist. } \\
\%\end{array}$ & 0.888 & 0.888 & 0.888 & 0.888 \\
\hline Digestible Treonine \% & 0.662 & 0.662 & 0.662 & 0.662 \\
\hline $\begin{array}{l}\text { Digestible Tryptophan } \\
\%\end{array}$ & 0.227 & 0.227 & 0.227 & 0.227 \\
\hline
\end{tabular}

*1Premix: Provided per kg of product: calcium $189.65 \mathrm{~g}$; sodium $37.5 \mathrm{~g}$; phosphorus $75 \mathrm{~g}$; fluorine $750 \mathrm{mg}$; retinol $67.5 \mathrm{mg}$; cholecalciferol $1.75 \mathrm{mg}$; tocopherol $1.27 \mathrm{mg}$; menadione $50 \mathrm{mg}$; thiamine $82,5 \mathrm{mg}$; riboflavin $212,5 \mathrm{mg}$; pyridoxine $125 \mathrm{mg}$; cobalamin $0.50 \mathrm{mg}$; pantothenic acid $375 \mathrm{mg}$; niacin $875 \mathrm{mg}$; folic acid 37,5 mg; biotin $5 \mathrm{mg}$; choline $4.875 \mathrm{mg}$; Cu $225 \mathrm{mg}$; Fe 1.125 
mg; Mn $2.500 \mathrm{mg}$; iodo 22,5 mg; Zn $750 \mathrm{mg}$; Se 12,5 mg; zinc bacitracin $550 \mathrm{mg}$; methionine $28,7 \mathrm{~g}$.

The poultry's mortality and eggs production were measured. In the end of each production cycle, the mean feed intake and the mean feed conversion ratio were evaluated. The body weight gain was measured in the end of the experimental period.

In the end of each production cycle, 72 eggs per treatment were evaluated regarding to the egg weight, specific gravity, the yolk and albumen height, the yolk and albumen diameter, the yolk color and weight and the yolk and albumen $\mathrm{pH}$.

The yolk color was evaluated in the end of each 21 days cycle by the same evaluator using the Roche ${ }^{\circledR}$ color fan. The yolk and albumen $\mathrm{pH}$ were measured by a bench $\mathrm{pH}$ meter.

To the eggshell analysis, the eggs were washed, sun dried during 72 hours and then, weighted. Two thickness points of the eggs shell were measured in the cross-sectional area of the eggs shell, which was possible to obtain a mean in millimeters $(\mathrm{mm})$. The thickness was analyzed by the digital pachymeter. The albumen weight was calculated by the subtraction: egg weight - (yolk weight + eggshell weight).
The Haugh Unit (HU), yolk index (YI) and albumen index (AI) were evaluated according to Seibel and Soares (2003):

- $\mathrm{HU}=100 \times \log$ (albumen height (mm) +7.57 - 1.7 x egg weight $\left.(\mathrm{g})^{0.37}\right)$;

- Albumen index $=$ albumen height (mm) / albumen diameter (mm);

- Yolk index = yolk height $(\mathrm{mm}) /$ yolk diameter $(\mathrm{mm})$.

The results were presented as the mean of all the studied production cycles, submitted to the analysis of variance and regression analysis, at 5\% probability, using the R software.

\section{RESULTS AND DISCUSSION}

The use of guava extract in the diet as an antioxidant additive did not improve the breeders' performance (Table 2). According to Bastos (2017), powdered cinnamon supplementation in the quails' diet in the laying phase improves the egg production because it can provide a balance in the organism through the antioxidant activity and the modulation of the gene's expression related to the antioxidant defense and the lipid metabolism. The guava extract had $2.13 \%$ of ellagic acid, which could have been not enough to result in lipid modulation and poultry production. 
Table 2 - Productive performance of japanese quail breeders fed guava extract in diet

\begin{tabular}{|c|c|c|c|c|c|c|}
\hline \multirow[t]{2}{*}{ Variable } & \multicolumn{4}{|c|}{ Guava extract levels } & \multirow{2}{*}{$\begin{array}{c}\mathrm{P} \\
\text { value }\end{array}$} & \multirow[t]{2}{*}{$\mathrm{CV}(\%)$} \\
\hline & $0.0 \%$ & $0.3 \%$ & $0.6 \%$ & $0.9 \%$ & & \\
\hline Feed intake $(\mathrm{g})$ & 22.38 & 22.73 & 22.03 & 22.38 & 0.3595 & 2.94 \\
\hline Egg production (\%) & 96.18 & 96.20 & 93.50 & 94.55 & 0.2431 & 2.77 \\
\hline $\begin{array}{l}\text { Feed conversion } \\
(\mathrm{kg} / \text { dozen })\end{array}$ & 0.380 & 0.391 & 0.394 & 0.390 & 0.2262 & 2.98 \\
\hline $\begin{array}{l}\text { Feed conversion ratio }(\mathrm{kg} / \mathrm{egg} \\
\text { mass) }\end{array}$ & 2.625 & 2.664 & 2.762 & 2.685 & 0.0699 & 3.16 \\
\hline Egg mass (kg) & 2.791 & 2.788 & 2.515 & 2.736 & 0.0662 & 5.02 \\
\hline Female body weight gain $(\mathrm{g})$ & 0.233 & 1.366 & 3.083 & 3.683 & 0.8577 & 367.42 \\
\hline Male body weight gain (g) & 4.866 & 5.066 & 6.833 & 0.250 & 0.4297 & 165.02 \\
\hline
\end{tabular}

$\mathrm{CV}-$ Coefficient of variation

The feed intake and the body weight gain were not affected by the guava extract in the diet, possibly because the diet was isonutritive. The feed intake monitoring is an important factor to take into consideration to use an additive ingredient in the diet. The use of an additive that results in a decrease of feed intake can impair its use in a commercial scale.

The eggs intern quality was influenced by the use of guava extract in the diet (Table 3). The yolk and albumen height, the Haugh Unit and the yolk and albumen index linearly decreased as the guava extract levels in the diet increased.
It was expected that the antioxidant improved the eggs biological membrane integrity, resulting in eggs with higher yolk and albumen. The guava extract ellagic acid was ineffective to improve the egg quality. Freitas et al. (2013) confirmed that the use of synthetic antioxidant or ethanolic mango extracts do not affect the breeder's performance, but it improves the albumen quality and the lipid eggs stability. Oliveira et al. (2018) verified that the use of copaiba and sucupira oils in the breeder's diet have a positive impact in the albumen quality and the yolk's $\mathrm{pH}$. Both oils have antioxidants properties. 
Table 3 - Egg quality produced by japanese quail breeders fed guava extract in diet

\begin{tabular}{|c|c|c|c|c|c|c|c|}
\hline \multirow[t]{2}{*}{ Variable } & \multicolumn{4}{|c|}{ Guava extract levels } & & \multicolumn{2}{|c|}{ P value } \\
\hline & $0.0 \%$ & $0.3 \%$ & $0.6 \%$ & $0.9 \%$ & $\begin{array}{l}\mathrm{CV} \\
(\%)\end{array}$ & Linear & Quad. \\
\hline Egg weight (g) & 12.084 & 12.233 & 11.914 & 12.112 & 1.93 & 0.5867 & 0.8024 \\
\hline Specific gravity & 1.071 & 1.072 & 1.072 & 1.072 & 1.89 & 0.9421 & 0.5530 \\
\hline Yolk height $(\mathrm{mm})^{1}$ & 11.514 & 11.082 & 11.178 & 10.970 & 1.81 & 0.0004 & 0.1835 \\
\hline Albumen height $(\mathrm{mm})^{2}$ & 4.597 & 4.293 & 4.093 & 4.074 & 5.91 & 0.0011 & 0.1187 \\
\hline Yolk diameter (mm) & 24.340 & 24.709 & 24.526 & 24.395 & 1.73 & 0.7553 & 0.5065 \\
\hline $\begin{array}{l}\text { Albumen diameter } \\
(\mathrm{mm})^{3}\end{array}$ & 40.230 & 40.889 & 41.852 & 40.228 & 2.81 & 0.4870 & 0.0358 \\
\hline Yolk color $^{4}$ & 5.560 & 5.550 & 5.913 & 5.537 & 4.08 & 0.4929 & 0.0498 \\
\hline $\mathrm{pH}$ of yolk & 6.160 & 6.152 & 6.160 & 6.195 & 0.88 & 0.2609 & 0.3438 \\
\hline $\mathrm{pH}$ of albumen & 9.092 & 9.148 & 9.110 & 9.084 & 0.69 & 0.5918 & 0.1112 \\
\hline Yolk percentage & 29.827 & 30.029 & 29.693 & 29.495 & 1.90 & 0.2120 & 0.4000 \\
\hline Eggshell percentage & 8.114 & 8.222 & 8.133 & 8.141 & 2.34 & 0.9958 & 0.5754 \\
\hline Albumen percentage & 62.134 & 61.634 & 62.088 & 62.0465 & 1.11 & 0.9173 & 0.4826 \\
\hline $\begin{array}{l}\text { Eggshell thickness } \\
(\mathrm{mm})\end{array}$ & 0.205 & 0.208 & 0.211 & 0.208 & 1.98 & 0.1642 & 0.2240 \\
\hline Haugh Unit ${ }^{5}$ & 89.458 & 87.444 & 86.488 & 86.386 & 1.70 & 0.0011 & 0.1175 \\
\hline Yolk Index $^{6}$ & 0.473 & 0.449 & 0.458 & 0.448 & 2.38 & 0.0034 & 0.1095 \\
\hline Albumen Index ${ }^{7}$ & 0.115 & 0.106 & 0.097 & 0.102 & 8.00 & 0.0065 & 0.0343 \\
\hline
\end{tabular}

${ }^{1} \mathrm{Y}=11,416-0,511 \mathrm{X}, \mathrm{R}^{2}=0,43$

${ }^{2} \mathrm{Y}=4,523-0,576 \mathrm{X}, \mathrm{R}^{2}=0,39$

${ }^{3} \mathrm{Y}=40,086+6,024 \mathrm{X}-6,339 \mathrm{X}^{2}, \mathrm{R}^{2}=0,28$, maximum point $=0,475 \%$

${ }^{4} \mathrm{Y}=5,505+1,010 \mathrm{X}-1,014 \mathrm{X}^{2}, \mathrm{R}^{2}=0,25$, maximum point $=0,498 \%$

${ }^{5} \mathrm{Y}=88,970-3,391 \mathrm{X}, \mathrm{R}^{2}=0,39$

${ }^{6} \mathrm{Y}=0,467-0,021 \mathrm{X}, \mathrm{R}^{2}=0,32$

${ }^{7} \mathrm{Y}=0,112-0,015 \mathrm{X}, \mathrm{R}^{2}=0,29$

Although the Haugh Unit was higher without the guava extract inclusion in the diet, all the Haugh Unit numbers were consistent with the AA norm, considered an optimal quality standard according to USDA (2000).

The yolk, albumen, eggshell and specific gravity percentage did not differ when the guava extract was used. According to Araújo et al. (2017), the eggshell quality affects the gas conductance and the eggs humidity, affecting the eggs humidity loss in the egg incubator. The specific gravity is a parameter that evaluates the eggshell quality and it did not differ with the treatments, indicating that there was no antioxidant action on the eggshell proteins in this study.

The albumen diameter increased quadratically as the guava extract levels were enhanced in the diet, reaching $0.475 \%$ of guava extractor maximum diameter. The highest albumen diameter is indicative of the egg quality loss and it is used to calculate the albumen index. Thus, the confirmed albumen index reduction resulted from the lower height and the biggest albumen index as the guava extract inclusion in the feed increased. 
The yolk color was affected by adding the guava extract in the breeder's diet, which the darkest color was with $0.498 \%$ of guava extract in the diet.

The use of guava extract in the quail diet with ellagic acid could be a viable and sustainable alternative in place of synthetic antibiotics. However, besides there was no improvement in the breeder's performance, there was a

\section{REFERENCES}

AHMED, S.T.; ISLAM, M.M.; BOSTAMI, A.R.; MUN, H.S.; KIM,Y.J.; YANG, C. J. Meat composition, fatty acid profile and oxidative stability of meat from broilers supplemented with pomegranate (Punica granatum L.) by-products. Food chemistry, v.188, p.481-488, 2015.

ARAÚJO, I.C.S.; LEANDRO, N.S.M.; MESQUITA, M.A.; CAFÉ, M.B.; MELLO, H.H.C.; GONZALES, E. Water vapor conductance: a technique using eggshell fragments and relations with other parameters of eggshell.

Revista Brasileira de Zootecnia, v. 46, n. 12, p. 896-902, 2017.

BARREIROS, A.L.B.S.; DAVID, J.M.; DAVID, J.P. Oxidative stress: relations between the formation of reactive species and the organism's defense.

Química Nova, v. 29, n. 1, p. 113-123, 2006.

BASTOS, M.S. Efeito da suplementação de canela sobre a expressão gênica, capacidade antioxidante e histomorfometria intestinal de codornas em fase de postura. 82p.; Dissertação (mestrado em worsening in the eggs internal quality, which could result in poorer newborn quail quality.

It was concluded that the use of guava extract as a zootechnic antioxidant in the Japanese quail breeders' diet did not affect their performance and did not improve the egg quality.

Zootecnia) -Universidade Federal de Sergipe, 2017.

CAMELO, L.C.L.; LANA, G.R.Q.; DOS SANTOS, M.J.B.; CAMELO, Y. A.R.P.; MARINHO, A. L.; RABELLO, C.B.V. Inclusão de farelo de goiaba na dieta de codornas européias. Ciência Animal Brasileira, v. 16, n. 3, p. 343349, 2015.

CRUZ-ATONIO, F.; SAUCEDOPOMPA, S.; MARTINEZ-VÁZQUEZ, G.; AGUILERA, A.; RODRÍGUEZ, R.; AGUILAR, C.N. Propiedades químicas e industriales del ácido elágico. Revista Científica de la Universidad Autónoma de Coahuila, v. 2, n. 3, p. 112, 2010.

DE CARVALHO, P.R.; PITA, M.C.G.; PIBER-NETO, E.; MIRANDOLA, R.M.S.; DE MENDONÇA-JÚNIOR, C. X. Influência da adição de fontes marinhas de carotenóides à dieta de galinhas poedeiras na pigmentação da gema do ovo. Brazilian Journal of Veterinary Research and Animal Science, v.43, n.5, p.654-663, 2006.

DEGÁSPARI C.H., WASZCZYNSKYJ, N. Propriedades antioxidantes de compostos fenólicos. Visão Acadêmica, v.5, n.1, p.33-40, 2004. 
DU, M.; AHN, D.U. Effects of

Antioxidants and Packaging on Lipid and Cholesterol Oxidation and Color Changes of Irradiated Egg Yolk Powder. Journal Of Food Science, v. 65, n.4, 2000.

FERREIRA, P.B. Cantaxantina e 25hidroxicolecalciferol e seus efeitos sobre os aspectos reprodutivos de galos. [Dissertação]. Santa Maria: Universidade Federal de Santa Maria, Centro de Ciências Rurais; 2010.

FREITAS, E.R.; SILVA BORGES, A., TREVISAN, M.T.S.; DA CUNHA, A.L.; DE MELO BRAZ, N.; WATANABE, P.H.; DO NASCIMENTO, G.A.J. Extratos etanólicos de manga como antioxidantes na alimentação de poedeiras. Pesquisa Agropecuária Brasileira, v. 48, n. 7, p. 714-721, 2013.

LIRA, R.C.; RABELLO, C.B.V.; FERREIRA, P.V.; LANA, G.R.Q.; LÜDKE, J.V.; DUTRA JUNIOR, W.M. Inclusion of guava wastes in feed for broiler chickens. Revista Brasileira de Zootecnia, v. 38, n. 12, p. 2401-2407, 2009.

MAHMOUD, R.; IBRAHIM, Doaa; BADAWI, M. Effect of supplementation of broiler diets with guava leaves and/or olive oil on growth, meat composition, blood metabolites and immune response. Benha Vet. Med. J, v. 25, p. 23-32, 2013.

OLIVEIRA, D.S.; AQUINO, P.P.; RIBEIRO, M.R.; PROENÇA, R.P.C.; SANT'ANA H.M.P. Vitamina C, carotenoides, fenólicos totais e atividade antioxidante de goiaba, manga e mamão procedentes da Ceasa do
Estado de Minas Gerais. Acta

Scientiarum Health Sciences, v.33, p89-98, 2011.

OLIVEIRA, M.D.D.; MELLO, H.H.C.; STRINGHINI, J.H.; MASCARENHAS, A.G.; ARNHOLD, E., CONCEIÇÃO, E. C. D., ... \& JÚNIOR, S. Antioxidant effect of the guava byproduct in the diet of broilers in the starter phase. Revista Brasileira de Zootecnia, v. 47, 2018 a.

OLIVEIRA, G.R.D.; LIMA, C.B.D.; RIBEIRO, L.M.C.S.; CAFÉ, M.B.; MOREIRA, J. D.S.; OLIVEIRA, E.M.D.; RACANICCI, A.M.C. Adição de óleo de copaíba (copaifera langsdorffii) e sucupira (pterodon emarginatus) na alimentação de poedeiras: qualidade física de ovos armazenados em diferentes temperaturas. Ciência Animal Brasileira, v.19, e41508, 2018.

PAPPAS, A.C.; ZOIDUS, E.; SURAI P.F.; ZERVAS, G. Selenoproteins and maternal nutrition. Comparative Biochemistry and Physiology Part B: Biochemistry and Molecular Biology, v. 151, n. 4, p. 361-372, 2008.

ROCHA, J.S.R.; BARBOSA, V.M.; LARA, L.J.C.; BAIÃO, N.C.;. CANÇADO, S.V.; LANA, A.M.Q.; POMPEU, M.A.; VASCONCELOS, R.J.C.; MACHADO, A.L.C.; MIRANDA, D.J.A.; FERNANDES, M.N.S.; MENDES, P.M.M. Efeito do armazenamento e da cantaxantina dietética sobre a qualidade do ovo fértil e o desenvolvimento embrionário. Arq. Bras. Med. Vet. Zootec., v. 65, n. 3, p. 792-800, 2013.

ROSTAGNO H.S.; ALBINO L.F.T.; DONZELE J.L. et al. Tabelas 
brasileiras para aves e suínos:

composição de alimentos e exigências

nutricionais. 3a ed. Viçosa. 2011; 252p.

SEIBEL, N.F.; DE SOUZA SOARES, L.A. Avaliação física de ovos de codorna em diferentes períodos de armazenamento. VETOR-Revista de Ciências Exatas e Engenharias, v. 13, n. 1, p. 47-52, 2003.

SEERAM, N.P.; ADAMS, L.S.; HENNING, S.M.; NIU, Y.; ZHANG, Y.; NAIR, M.G.; HEBER, D. In vitro antiproliferative, apoptotic and antioxidant activities of punicalagin, ellagic acid and a total pomegranate tannin extract are enhanced in combination with other polyphenols as found in pomegranate juice. The Journal of nutritional biochemistry v.16, n.6, p.360-367, 2005.

SILVA, E.P.; RABELLO, C.B.V.; DUTRA JÚNIOR, W.M.; LOUREIRO, R.R.D.S.; GUIMARÃES, A.A. D.S.; LIMA, M.B.D.; BARBOSA-LIMA, R. Análise econômica da inclusão dos resíduos de goiaba e tomate na ração de poedeiras comerciais. Revista

Brasileira de Saúde e Produção Animal, v. 10, n. 4, 2009.

USDA. United States Department of Agriculture. Egg-Grading Manual. Washington. 2000. [acesso 23 Out 2016]. n75. Disponível em: http://www.ams.usda.gov/AMSv1.0/get file?dDocName $=$ STELDEV3004502 